\title{
Tourists' Satisfactory Level in Terms of Tourism Infrastructures in Melaka, Malaysia: A Study on International Students in Universiti Teknologi Malaysia (UTM)
}

\author{
Meysam Ramyar ${ }^{1^{*}}$, Zia ur Rahman Zaheer ${ }^{2}$, Norhazliza Halim ${ }^{3}$, Mohammad Jafar Ghasemi ${ }^{4}$ \\ ${ }^{I}$ Faculty of Build Environment and Surveying, UTM, Johor Malaysia \\ ${ }^{2}$ Department of English language and Literature, Faculty of Literature and Humanities, Baghlan University, \\ Afghanistan \\ ${ }^{3}$ Faculty of Build Environment and Surveying, UTM, Johor Malaysia \\ ${ }^{4}$ Department of Tourism, University of Mazandaran
}

*Corresponding Author: Meysam Ramyar, Faculty of Build Environment and Surveying, UTM, Johor, Malaysia

\begin{abstract}
This research aims at exploring the UTM international students' level of satisfaction from the tour of Melaka. The objectives of the study are; to investigate the level of satisfaction of international students in UTM of Melaka tour, to explore the international students' satisfactory level towards accessibility facilities from the Melaka tour, and to Study the international students' satisfactory level towards facilities from Melaka tour. The study is carried among 100 international students in UTM. Among the respondents, sixty (60) were male, while forty (40) of them were female aging between 18 and 50. The findings revealed that they were more satisfied with the quality of accommodations services compared to accessibilities and facilities.
\end{abstract}

Keywords: Infrastructures, Level of Satisfaction, Facilities, Accommodation, Accessibility

\section{INTRODUCTION}

Universiti Teknologi Malaysia UTM is an international university. 28110 students are pursuing postgraduate and undergraduate degrees. Among 4461 are international students from seventy-two different courtiers around the world studying in various faculties (UTM 2019). Universiti Teknologi Malaysia international UTMi has established international Students Societies ISS for all the national and international students. UTMi arranges tours for every International Students Society (ISS) once in a semester to different states of Malaysia.

Melaka is one of fourteen Malaysian nations. Melaka is situated on Peninsular Malaysia's southwestern shore. Melaka city is $1,658 \mathrm{~km} 2$ and is split into three districts, namely Melaka Tengah, Alor Gajah, and Jasin. Traveling by road from Kuala Lumpur to Melaka requires about two hours, and going by route to Singapore for around three hours. Melaka is a well-known historical state that has, for decades, been rich with numerous tourism destinations. Besides, tourism was the most significant economic field in the state under the services sector, contributing 46.6 percent to GDP (Amir et al., 2015). Thus, UTMi arranges tours for international students to Melaka once a semester. There is a lack of studies on international students' level of satisfaction in terms of tourism infrastructures. Therefore, this study aims to explore the students' level of satisfaction regarding accessibility, accommodation, and facilities from the Melaka tour.

\subsection{Research Objectives}

1. To investigate the international students' satisfactory level towards Accommodation services from Melaka tour.

2. To explore the international students' satisfactory level towards accessibility services from Melaka tour. 
3. To Study the international students' satisfactory level towards facilities from Melaka tour.

\section{Methodology}

The study is based on a quantitative approach where quantitative data is collected to investigate the students' level of satisfaction with the Melaka tour in terms of tourism infrastructures. The population of the study consists of one hundred international students in Universiti Teknologi Malaysia UTM, including undergraduate and postgraduate students. The population comprises of sixty male and forty female students from different countries around the world aging between eighteen to fifty years. The questionnaire used for the data collection is divided into two parts, namely, respondents' demographics and tourism infrastructures. Furthermore, the tourism infrastructure is divided into three parts, such as accommodation, accessibility, and facilities. The students were asked to show their level of satisfaction by ranking the items as 1. Poor, and 5. Good. Besides, all one hundred questionnaires were successfully collected.

\section{TOURISM}

Tourism is considered a social, cultural, and economic phenomenon that includes moving people to countries or places for personal or business / professional purposes outside of their healthy environment. Such people are called visitors (who can be either tourists or excursionists; residents or non-residents), and tourism is linked to their activities, some of which include spending on tourism. (UNWTO, 2010). Tourism is a dynamic industry, according to the United Nations World Tourism Organization (UNWTO), which is a fundamental economic force for socio-economic growth in a variety of areas and destinations worldwide. Tourism is a full initiative of transport, airlines, tour operators, hotel companies, ferry companies, the information technology industry, and the tourism host community of tourism destinations (UNWTO 2011). The rising population of the elderly and disabled need special assistance and service not only in Europe but throughout the world, created the latest emerging new market as accessible tourism in the tourism industry.

Also, tourism is a series of events, services, and industries that offer a travel experience that includes transportation, lodging, eating and drinking facilities, retail shops, entertainment and other hospitality services provided for individuals or groups traveling away from home"(Kalaiya et al., 2015).

\section{TOURIST SATISFACTION}

Severt et al. (2007) describe tourist satisfaction as the degree to which the enjoyment of fulfilment of the tourist emerged from the trip experience of a product or service that fulfils the needs, aspirations, and wishes of the tourist under the trip. A comparison of the customer's expectations before and after intake induces satisfaction. Throughout the tourism sense, satisfaction is specifically referred to as a function of perceptions about pre-travel and post-travel experiences. If encounters go beyond expectations, the visitor is happy. Nonetheless, if the visitor feels unhappiness, the predicted result would be a disappointment (Reisinger \& Turner, 2003). From the above topic, it is clear that there are two different factors affecting tourist satisfaction: Firstly, it relates to the tourist's pre-expectation before the journey; and secondly, it relates to the tourist's justification of the services offered after the trip, and to the real encounters.

\section{TOURISM INFRASTRUCTURES}

Tourism facilities are an essential part of physical infrastructure, which is a necessary pillar of overall economic growth and tourism growth (Khadaroo \& Seetanah, 2007). They form the constituent, called tourism infrastructure, along with hotels and other hospitality facilities. Each of these elements enhances the growth of tourism primarily by increasing a destination's attractiveness and competitiveness. In their chosen destination, tourists expect to be comparable with what they enjoy at home, particularly those that have become the essential element of recreation in everyday life (Murphy et al., 2000).

In a broader context, the infrastructure comprises physical, legal, environmental, and mental services that lead to the fun, efficient, and sustainable tourism commodity (Khadaroo \& Seetanah, 2007). The physical infrastructure of direct relevance to tourism includes recreational facilities that form a crucial tourism infrastructure along with hotels and other types of accommodation, spas, and restaurants. All definitions, however, are broad, revolutionary, and confined mainly by limits of individual awareness 
and national policies. Defining the tourism system correctly is better said than achieved. Perhaps since tourism is not a single sector, there is no well-specified system for tourism (Dwyer et al. 2010).

\subsection{Accommodation}

Akyeampong (2007) describes tourist accommodation as an institution which offers individuals or groups its facilities and services. Examples include, but are not limited to, restaurants, motels, guesthouses, and apartments/chalets for businesses. Nevertheless, it can be described in its entirety as any facility offering a psychological base for visitors or individuals who are temporarily away from their regular place of residence or work (Mensah \& Dei-Mensah, 2013).

The bedrooms are necessarily the main items provided to their customers by the lodging facilities. Nonetheless, a range of other amenities and resources eligible for rent include restaurants and bars (food and beverage), leisure amenities (swimming pools, basketball courts, horseback riding), fitness centers (spas) and conference and meeting rooms for guests to use among others. In modern days, owing to the rise of business travel, the hospitality facilities put a significant focus on conferencing and meetings.

\subsection{Accessibility}

Accessible tourism enables individuals with access needs, including independence, vision, hearing, and cognitive access attributes, to work individually and with equality and integrity through the delivery of widely built tourism goods, facilities, and ecosystems, which encompasses persons in wheelchairs alone or with assistance, support sticks or crutches, elderly visitors with trolleys and bulky baggage, vision and auditory impairments, veterans, households of prams, and pregnant people who are required to travel regularly as they desire (Darcy \& Dickson 2009).

Visitors with disabilities want to access the resources and amenities without any limitation by the service provider to spend their fun leisure time at the famous tourism destination. Therefore travellers with disabilities require special assistance and help at the goal. Exceptional support for visitors with disabilities is based on the regular public transit, lodging, and travel facilities program. Nevertheless, specific offerings that keep a consumer happier will be well informed regarding extra service, donation, incentive, or economic benefits (Ideas 2012) the essence of the service provider.

\subsection{Facility}

Tourist facilities are tourist or visitor services such as lecture rooms, restaurants, gift shops, toilets and leisure facilities which do not provide a hotel or tourist accommodation; 'transport effect analysis' means a review of the transport effect created by a proposed development on the current and projected road system, Recommendation of mitigation steps required as a consequence of the impact; 'Mobility Management Strategy' implies a proposal or strategy detailing how mobility needs are to be fulfilled in all forms of transport, such as (but not limited to) public transport, Private travel, commuting and walking, including how parking needs can be accommodated on including off the site, and what parking relevant facilities would be required; 'transport usage' provides land use, building or arrangement for the provision of a public goods travel facility (including liquids and gases) Or passengers by train, bridge, sea or pipeline, including the usage of specific property, buildings or facilities for the purposes of a dock, railway station, bus depot or taxi interchange, a travel undertaking focused on the provision of a transport service; It involves a public private project such as a train station, a bus terminal, a taxi rank, an intersection of public transit, a harbour it ancillary uses, which does not have an airport or a helicopter landing pad; 'urban planting' implies the growing of crops in comparatively limited industrial or peripheral areas; For own use or selling in neigh dull markets; given that, for the purposes of this planning management system, the planting of a garden in a dwelling by an individual is not treated as urban agriculture; 'used' includes 'designated or planned to be used' in addition to its specific meaning; Utility implies a usage or facilities needed to provide engineering and related resources for the proper functioning of urban growth, which requires a water reservoir (law insider).

\section{TOURISM IN MALAYSIA}

Over the last ten years, Malaysia has seen a significant rise over visitor arrivals. The problem is to maintain this development, and so it is necessary to consider the factors driving Malaysia's inbound tourism. In the last three decades, tourism in Malaysia has been one of the main contributors to the 
Malaysian GDP. In turn, in 2013, Malaysia provided 1,795,500 jobs, of which some 6.5 percent of total employment in the tourism sector was produced. The research deals with the exploitation of tourist expenditure in five tourism industries, lodging, food and drinks, culture, shopping, and transportation are contributing to direct benefits for the city (Amir et al., 2015\& Nijat et al., 2019).

Malaysia has strengthened its tourism ranking since 2000, from the world's 17th most popular destination to the 10th in 2012 (WTO, 2013). In 2014, Malaysia recorded over 27 million overseas visitor arrivals and 23 billion US\$ in receipts for tourism (Ministry of Tourism Malaysia, 2015). According to the World Tourist Organization (WTO), the government has called for expanded tourism in Malaysia in an attempt to diversify the market and make Malaysia's market less dependent on exports. As a result, tourism has been the third-largest producer of foreign-exchange revenue in Malaysia and accounted for 7 percent of Malaysia's economy since 2005.

\section{TOURISM IN MELAKA}

Melaka is one of fourteen Malaysian nations. It is situated on Peninsular Malaysia's south-western shore. Melaka city is $1,658 \mathrm{~km} 2$ and is split into three districts, namely Melaka Tengah, Alor Gajah, and Jasin. Traveling by road from Kuala Lumpur to Melaka requires about two hours, and going by ways to Singapore for around three hours. Melaka is a well-known historical state that has, for decades, been rich with numerous tourism destinations. Besides, tourism was the most significant economic field in the country under the services sector, contributing 46.6 percent to GDP (Amir et al., 2015).

Melaka was seen as a historical and heritage witness to 500 years of trading and cultural interactions between East and West in the Melaka Straits. UNESCO is also assisting Melaka to conserve and rebuild the precious colonial houses, squares, and churches left in the 15th century by Portuguese, Dutch, and British. Amid UNESCO recognition, Melaka is now becoming the node of domestic and foreign visitors with the highest number reported in 2012, at 13,711 million visitors. In 2012 they drew 1,366 million local visitors, equivalent to 3,512 million in 2007 (Amir et al., 2015).

\section{FINDINGS}

\subsection{Respondents' Demographics}

The table below shows the participants' demographics including age, gender and their educational qualification.

Table1.1. Demographics

\begin{tabular}{|c|c|c|}
\hline \multirow{4}{*}{ Age } & Category & Number of students \\
\cline { 2 - 3 } & $18-24$ & $26 \%$ \\
\cline { 2 - 3 } & $25-34$ & $48 \%$ \\
\cline { 2 - 3 } & $35-50$ & $26 \%$ \\
\hline \multirow{2}{*}{ Gender } & Male & $60 \%$ \\
\cline { 2 - 3 } & Female & $40 \%$ \\
\hline \multirow{3}{*}{ Education } & Undergraduate & $36 \%$ \\
\cline { 2 - 3 } & Master & $36 \%$ \\
\cline { 2 - 3 } & PhD & $28 \%$ \\
\hline & & $\mathbf{1 0 0}$ \\
\hline
\end{tabular}

Table 1.1 describes the respondents' background information. Most of the respondents are aging between 25-34 years, with $48 \%$ and $60 \%$ are male, while $40 \%$ are female students among the participants. $36 \%$ of the respondents are undergraduate, and the same $36 \%$ are pursuing their master's degree, while $28 \%$ of the subjects are doing their Ph.D.

\subsection{Participants' Satisfactory Level of Accessibility, Accommodation and Facilities}

Table 2.1 indicates the overall mean, standard deviation and percentage of accessibility, accommodation and facilities regarding respondents' level of satisfaction from Melaka tour.

Table2.1. Accessibility, Accommodation, Facilities

\begin{tabular}{|c|c|c|c|c|}
\hline \multicolumn{5}{|c|}{ Accessibility, Accommodation, Facilities } \\
\hline & $\mathrm{N}$ & Mean & Std. Deviation & Percentage \\
\hline Accommodation & 100 & 3.50 & 0.87 & $70 \%$ \\
\hline
\end{tabular}


Tourists' Satisfactory Level in Terms of Tourism Infrastructures in Melaka, Malaysia: A Study on International Students in Universiti Teknologi Malaysia (UTM)

\begin{tabular}{|l|l|l|l|l|}
\hline Accessibility & 100 & 3.32 & 0.87 & $66.4 \%$ \\
\hline Facilities & 100 & 3.23 & 0.88 & $64.6 \%$ \\
\hline
\end{tabular}

Table 1.1 shows that the respondents' level of satisfaction from the Melaka tour. The participants have ranked the accommodation at the first level with $70 \%(\mathrm{M}=3.50, \mathrm{SD}=0.87)$, followed by accessibility in second place with $66.4 \%(\mathrm{M}=3.32, \mathrm{SD}=0.87)$, while facilities from Melaka tour is ranked at third level with $64.6 \%(\mathrm{M}=3.23, \mathrm{SD}=0.88)$.

\subsection{Respondents' Satisfactory Level of Accommodation}

Accommodation is when people want to travel to another destination or on a trip such as parks, campsites, and mountains. They are provided rooms or buildings to stay or live in and are considered very important to any tourist. Table 3.1 describes the respondents' level of satisfaction with the Melaka tour.

Table3.1. Accommodation

\begin{tabular}{|l|l|l|l|l|}
\hline Accommodation & N & Mean & Std. Deviation & Percentage \\
\hline & 100 & 3.60 & 0.98 & $72 \%$ \\
\hline Tent sites in summer & 100 & 3.57 & 1.01 & $71.4 \%$ \\
\hline Suit quality and service & 100 & 3.55 & 1.04 & $71 \%$ \\
\hline Hotel quality and service & 100 & 3.52 & 0.97 & $70.4 \%$ \\
\hline Campaign areas and services & 100 & 3.49 & 1.10 & $69.8 \%$ \\
\hline Motel quality and service & 100 & 3.32 & 1.18 & $66.4 \%$ \\
\hline Home stay quality and services & & & \\
\hline
\end{tabular}

For accommodation, the respondents' ranked it to be at the second level in this study. The participants numbered the tent sites in summer with $72 \%(\mathrm{M}=3.60, \mathrm{SD}=0.98)$, followed by the suit quality and services with $71.4 \%(\mathrm{M}=3.57, \mathrm{SD}=1.01)$, while the subjects levelled the home stay quality and services with $66.4 \%(\mathrm{M}=3.32, \mathrm{SD}=1.18)$.

Besides, the hotel quality and service were ranked with $71 \%(\mathrm{M}=3.55, \mathrm{SD}=1.04)$ from Melaka tour, followed by complaint areas and facilities with $70.4 \%(\mathrm{M}=3.52, \mathrm{SD}=0.97)$, and the subjects marked the motel quality and services with $69.8 \%(\mathrm{M}=3.49, \mathrm{SD}=1.10)$.

\subsection{Participants' Level of Satisfactory of Accessibility}

The accessibility in this study is ranked to be at the second level. The table below describes the respondents' level of satisfaction of accessibility from Melaka tour.

Table4.1. Accessibility

\begin{tabular}{|l|l|l|l|l|}
\hline Accessibility & $\mathrm{N}$ & Mean & Std. Deviation & Percentage \\
\hline & 100 & 3.72 & 0.93 & $74.4 \%$ \\
\hline Quality of roads & 100 & 3.47 & 1.01 & $69.4 \%$ \\
\hline Internal transport & 100 & 3.47 & 0.96 & $69.4 \%$ \\
\hline Trails and observation points for bird watching & 100 & 3.45 & 1.16 & $69 \%$ \\
\hline Bridges and walkways & 100 & 3.36 & 0.99 & $67.2 \%$ \\
\hline Cycling routes & 100 & 3.35 & 1.06 & $67 \%$ \\
\hline Paths \& walking tracks & 100 & 3.15 & 1.05 & $63 \%$ \\
\hline Excursionist on wheelchair & 100 & 3.09 & 1.20 & $61.8 \%$ \\
\hline Excursionist walker & 100 & 2.90 & 1.43 & $58 \%$ \\
\hline Skiing routes & & & \\
\hline
\end{tabular}

For the accessibility, the participants ranked the quality of roads with a mean of $74.4 \%(\mathrm{M}=3.72$, $\mathrm{SD}=0.95)$, and the respondents ranked the internal transport with $69.4 \%(\mathrm{M}=3.47, \mathrm{SD}=1.01)$ while they marked the Skiing routes with low 58\% ( $\mathrm{M}=2.90, \mathrm{SD}=1.43)$.

Besides, Cycling routes with $67.2 \%(\mathrm{M}=3.36, \mathrm{SD}=0.99)$ and the Excursionist on wheelchair with $63 \%$ $(\mathrm{M}=3.15, \mathrm{SD}=1.05)$ followed by Excursionist walker with 61.8\% $(\mathrm{M}=3.09, \mathrm{SD}=1.20)$.

\subsection{Respondents' Level of Satisfaction of Facilities}

Facilities means services provided for tourists or visitors during a tour such as lecture rooms, restaurants, gift shops, restrooms and recreational facilities. The following table describes the respondents' level of satisfactory from Melaka tour. 
Tourists' Satisfactory Level in Terms of Tourism Infrastructures in Melaka, Malaysia: A Study on International Students in Universiti Teknologi Malaysia (UTM)

Table5.1. Facilities

\begin{tabular}{|l|l|l|l|l|}
\hline Facilities & $\mathrm{N}$ & Mean & Std. Deviation & Percentage \\
\hline Multipurpose hall & 100 & 3.86 & .92 & $77.2 \%$ \\
\hline Availability of high-speed internet and Wi-Fi & 100 & 3.70 & 1.07 & $74 \%$ \\
\hline Paved roadways & 100 & 3.68 & 1.05 & $73.6 \%$ \\
\hline Health centre & 100 & 3.57 & 1.05 & $71.4 \%$ \\
\hline Bike service/ hire shop & 100 & 3.49 & 1.04 & $69.8 \%$ \\
\hline Parking areas & 100 & 3.45 & 1.25 & $69 \%$ \\
\hline GPS and map for Orienteering & 100 & 3.44 & 1.04 & $68.8 \%$ \\
\hline Signage for vehicles and pedestrians & 100 & 3.37 & 1.17 & $67.4 \%$ \\
\hline Tourism information centre & 100 & 3.30 & 1.08 & $66 \%$ \\
\hline Toilet cleanliness and washing equipment's & 100 & 3.29 & 1.04 & $65.1 \%$ \\
\hline Garbage bin & 100 & 3.26 & 0.96 & $65.2 \%$ \\
\hline Backpacker facilities like kitchen, laundry and lounge & 100 & 3.19 & 1.11 & $63.8 \%$ \\
\hline Interpretational signs for trees and fauna & 100 & 3.16 & 1.13 & $63.2 \%$ \\
\hline Café and restaurant & 100 & 3.07 & 1.05 & $61.4 \%$ \\
\hline Spotlight in trekking routes for night & 100 & 3.06 & 1.22 & $61.2 \%$ \\
\hline Climbing equipment's & 100 & 2.95 & 1.08 & $59 \%$ \\
\hline Rafting facilities & 100 & 2.82 & 1.38 & $56.4 \%$ \\
\hline GPS and map for Orienteering & 100 & 3.44 & 1.04 & $68.8 \%$ \\
\hline
\end{tabular}

The respondents showed their level of satisfaction from the Melaka tour by ranking the item 'multipurpose hall in facilities' with $77.2 \%(\mathrm{M}=3.86, \mathrm{SD}=0.92)$ followed by the availability of highspeed internet and Wi-Fi with 74\% (M=3.70, $\mathrm{SD}=1.07)$. Furthermore, the subjects marked health center in with $71.4 \%(\mathrm{M}=3.57, \mathrm{SD}=1.05)$, while the Rafting facilities with a low $56.4 \%(\mathrm{M}=2.82$, $\mathrm{SD}=1.38$ ).

Besides, the subjects numbered the GPS and map for Orienteering with $68.8 \%$ (M=3.44, SD=1.04) and the Tourism information center with $66 \%(\mathrm{M}=3.30, \mathrm{SD}=1.08)$. Moreover, the participants were satisfied with backpacker facilities like kitchen, laundry, and lounge with $63.8 \%(\mathrm{M}=3.19, \mathrm{SD}=1.11)$.

\section{DISCUSSION}

In the previous chapter, it is highly emphasized that tourists' satisfaction is related to tourism infrastructures. Tourism infrastructures in this study are divided into three categories, namely; accommodation, accessibility, and facilities. The findings revealed that the respondents were more satisfied with the services related to accommodation in comparison to the services of accessibility and facilities. In research conducted by Shahrivar (2012), investigating the importance of tourist satisfaction. The results indicated that it is necessary to measure the tourist's satisfaction and the factors affecting it. Furthermore, research conducted by Lee et al. (2011), the results indicated that tour quality affects tourist satisfaction, which indirectly influences tourist loyalty by lowering tourist complaints.

Firstly, the researcher has emphasized students' satisfactory level towards accommodation services in Melaka. Thus, the result obtained indicated that the international tourists were more satisfied with tents' services, suit, and hotels' service, but they were dissatisfied with Home stay quality and services. In support of the findings of this research a study conducted by Hasegawa, (2010). The results revealed that the tourists who stayed at hotels were more satisfied with accommodation facilities

Meanwhile, the students' satisfactory levels towards accessibility services from the Melaka tour have been explored by the researcher. It was found that the subjects were satisfied with the quality of roads, internal transport and trails and observation points of bird watching. Still, the participants were not satisfied with the services of skiing routes where they showed no interest. In line with this research, a study conducted by Sukiman, Omar, Muhibudin, Yussof, and Mohamed (2013), it was revealed in the results showed that the participants were satisfied with the accessibility services.

Next, the participants showed their satisfaction in terms of the services related to facilities such as multipurpose hall, availability of high-speed internet, health center, and bike service/hire shop. Still, they were not satisfied with some other services in facilities, for instance, climbing equipment and 
rafting facilities. A study conducted by Yu and Goulden (2006), the results revealed that international tourists were more satisfied with the services of facilities such as food, parking areas, and tourism information center (TIC). Mostly, tourists like to visit the jungles in Mongolia where there are no internet facilities available, but in Melaka, there is an availability of high-speed internet.

\section{LiMitATIONS}

Limitations of the study include; all the international students have not facilitated the questionnaires to take part in the survey. Besides, the researcher should have conducted interviews to gather in-depth information regarding the respondents' level of satisfaction. The researcher has only used the questionnaire as a data collection tool.

\section{CONCLUSION}

The study investigated the satisfactory level of international students' in UTM from the Melaka tour. It has been postulated that the international students were more satisfied with the quality of accommodations services compared to accessibilities and facilities. They were satisfied with the accommodation services in terms of tent sites in summer while the participants were dissatisfied form the services such as home stay quality and services. Accessibilities were the second indicator where the respondents showed their level of satisfaction. They were satisfied with the quality of roads and internal transport but dissatisfied with the services of Excursionist walkers and skiing routes. However, facilities were ranked as the least satisfactory indicator by international students from the Melaka tour. They were more satisfied with the multipurpose hall as well as the availability of highspeed internet and Wi-Fi but showed their concerns with climbing equipment and rafting facilities.

\section{REFERENCES}

[1] Akyeampong, O. A. (2007). Tourism in Ghana: The accommodation sub- sector. Accra, Ghana: Janel Publications.

[2] Amir, S., Osman, M. M., Bachok, S., \& Ibrahim, M. (2015). Sustaining local community economy through tourism: Melaka UNESCO world heritage city. Procedia Environmental Sciences, 28, 443-452.

[3] Dwyer, L., Forsyth, P., Dwyer, W. (2010), Tourism Economics and Policy, Bristol, Buffalo, Toronto, Channel view publications.

[4] Darcy S., Dickson, T.2009. A whole life Approach to Tourism. Accessed 2.4.2012

[5] Hasegawa, H. (2010). Analyzing tourists' satisfaction: A multivariate ordered probit approach. Tourism Management, 31(1), 86-97.

[6] https://www.lawinsider.com/dictionary/tourist-facilities

[7] http://ideas.repec.org/a/ora/journl/v1y2010i2p1154-1157.html

[8] https://www.unwto.org/glossary-tourism-terms

[9] http://travel-to-malaysia.com/malaysia-is-ninth-most-visited-in-the-world-in-unwto-list/

[10] http://www.motac.gov.my/en/

[11] Kalaiya, A. B., \& Kumar, A. (2015). Tourism as a development tool: A study on role of tourism in economic development, employment generation and poverty reduction: Special focus on Kachchh. International Journal, 3(7), 189-197.

[12] Khadaroo, J., Seetanah, B. (2007), "Transport infrastructure and tourism development", Annals of Tourism Research, Vol. 34, No. 4, pp. 1021-1032. DOI: 10.1016/j.annals.2007.05.010

[13] Lee, S., Jeon, S., \& Kim, D. (2011). The impact of tour quality and tourist satisfaction on tourist loyalty: The case of Chinese tourists in Korea. Tourism Management, 32(5), 1115-1124.

[14] Murphy, P., Pritchard, M.P., Smith, B. (2000), "The destination product and its impact on traveller perceptions", Tourism Management, Vol. 21, No. 1, pp. 43-52. DOI

[15] Mensah, I., \& Dei-Mensah, R. (2013). Management of tourism and hospitality services (2nd ed.). Cape Coast, Ghana: Edsam Press Ltd.

[16] Nijat, N., Atifnigar, H., Chandran, K., Selvan, S. L. T., \& Subramonie, V. (2019). Psychological Factors that Affect English Speaking Performance among Malaysian Primary School Pupils. American International Journal of Education and Linguistics Research, 2(2), 55-68.

[17] Reisinger, Y., \& Turner, L. W. (2003). Cross-cultural Behaviour in Tourism: Concepts and Analysis. Oxford: Butterworth-Heinemann. 
[18] Severt, D., Wong, Y., Chen, P., \& Breiter, D. (2007). Examining the motivation, perceived performance and behavioural intentions of convention attendees: Evidence from a regional conference. Tourism Management, 28(2), 399-408.

[19] Sukiman, M. F., Omar, S. I., Muhibudin, M., Yussof, I., \& Mohamed, B. (2013). Tourist satisfaction as the key to destination survival in Pahang. Procedia-Social and Behavioral Sciences, 91, 78-87.

[20] Shahrivar, R. B. (2012). Factors that influence tourist satisfaction. Journal of Travel and Tourism Research (Online), 12(1), 61.

[21] Yu, L., \& Goulden, M. (2006). A comparative analysis of international tourists' satisfaction in Mongolia. Tourism management, 27(6), 1331-1342. 